\title{
THE EFFECT OF BRAND IMAGE, LIFESTYLE, AND PRICE ON BUYING DECISION ONLINE TRANSPORTATION SERVICE WITH PURCHASE INTENTION AS A MEDIATION :STUDY ON GOJEK CUSTOMERS IN BANDA ACEH CITY
}

\author{
Suci Sarah, PermanaHonneytaLubis and Ahmad Nizam \\ Magister Manajemen, UniversitasSyiah Kuala, Indonesia \\ http://doi.org/10.35409/IJBMER.2021.3239
}

\begin{abstract}
This study intends to examine the effect of brand image, lifestyle, and price on buying decisions for gojek transportation services with purchase intention as a mediating variable. The sample taken was consumers of Gojekonline transportation service users in the city of Banda Aceh using a non-probability sampling method with a quota sampling technique so that a sample of 197 people was obtained. Data were analyzed in the form of Structural Equation Modeling (SEM) through the use of Amos software. The research found that brand image, lifestyle, and price directly influence purchase intentions; brand image, lifestyle, price, and purchase intention influence buying decisions, and; purchase intention partially mediates the influence of lifestyle and the effect of price on buying decisions. The novelty lies in the finding of purchase intention which acts as a partial mediator in the use of online transportation services in Banda Aceh. For further research, which can be devoted to online transportation, and the addition of other variables such as gender, distance, or others as moderating variables, which can be an indication of decisions about using online transportation. For practitioners, especially manufacturers of online transportation services, this research model can be the basis for re-establishing service strategies for the work area of the city of Banda Aceh. Producers need to pay attention to social status, expenditure for important things, tariffs, and preferential interests of producers in the future, in order to find the right strategy formulation to increase the use of society in online transportation services.
\end{abstract}

Keyword: Brand Image, Lifestyle, Price, Buying Decision, Purchase Intention.

\section{INTRODUCTION}

One aspect of life that is affected by the development of information technology is transportation services. This development has had a major impact on the transportation sector where almost all types of transportation are online or application-based. A very fierce level of competition is also shown in this sector, so that service providers must continue to think innovatively to develop their business and increase customer interest in continuing to choose the services they have.

Starting to increase public interest in online transportation, online-based transportation service companies are competing to present unique service alternatives in order to create satisfaction for their consumers. In conditions of very tight competition like today, the thing that must be prioritized is the consumer's decision to choose online transportation service products, preceded 


\section{International Journal of Business Management and Economic Review}

Vol. 4, No. 02; 2021

ISSN: 2581-4664

by a purchase intention, namely the desire to use these services with various assumptions of choice of available online transportation services.

Increased competition and rapid technological changes in online transportation services are currently very important for consumer satisfaction and also determine consumer decisions to choose transportation services that suit customer needs and desires. Currently, in Banda Aceh, Indonesia, there are three (3) online transportation service companies that market their products, namely Gojek, Grab, and Maxim. Of the three companies that provide online transportation ordering services, Gojek is a pioneer in the history of online transportation development both in Indonesia and in Banda Aceh. In a span of 12 (twelve) months, Gojek has continued to develop from a new mobile application to become a major service. There are many types of menus for the services offered by the Gojek application. This then provoked resistance from its competitors by continuing to also bring up new menus.

Grab is also currently an alternative transportation service for people in the city of Banda Aceh. Grab provides the most popular transportation service application in Southeast Asia, where the application service is to connect passengers and drivers throughout Southeast Asia. Furthermore, the online transportation service in Banda Aceh is Maxim, which is a transportation service that also helps passengers and drivers connect. This Maxim has been operating for more than 15 years in various countries. Maxim company does not only focus on taxis but also types of transportation services such as motorbikes or cars in general.

Of the three types of online-based transportation tools or applications, since 2018, Gojek has dominated transportation in Indonesia, where through the website http://tek.id/, it is known that the number of Gojek service users has reached 19 million users per year. Its closest competitor is Grab with 14 million users per year. In the face of the high number of enthusiasts and the high level of competition, these online or application-based service providers continue to innovate in developing their products by providing various types of services not only in shuttle services, delivery services, but also online-based payment services. Not only that, to reduce the level of competition, service providers also reduce prices for each type of service that is affordable by all types of economic lines of society.

In online transportation, you can make payments via non-cash, with non-cash transaction services on each service application available on the online transportation. To increase public interest in online transactions, transportation service providers provide various types of offers that are beneficial to the user community such as promos, which can be used for shopping transaction services at stores, restaurants, e-commerce that have been registered as business partners of each online transportation application. the. Non-cash transaction facilities are made easier, faster, and more economical. Spending is more economical because of the many promos or discounts that are regularly given. This can increase interest and buying decisions through online.

However, online buying decisions in Banda Aceh are still relatively low, this is evidenced by the results of the initial survey the researchers conducted where the average value of buying decisions on online transportation was 3.15 on the Likert scale unit, which indicates that online transportation buying decisions are still heavily influenced by several other factors. In addition, low consumer buying decisions are also influenced by consumer purchase intentions. Similar results are also shown from online purchase intentions in the city of Banda Aceh, where the initial survey results obtained a mean of 3.19 on a Likert scale, this value shows that online 


\section{International Journal of Business Management and Economic Review}

Vol. 4, No. 02; 2021

ISSN: 2581-4664

purchase intentions in the city of Banda Aceh are still low.

The low level of online buying decisions in the city of Banda Aceh and the intention to purchase online in the city of Banda Aceh is caused by brand image, lifestyle, price, and several other factors. For this reason, researchers conducted comprehensive research on the influence of a brand image, lifestyle, and price on buying decisions for gojek transportation services with purchase intention as a mediating variable in the city of Banda Aceh.

\section{LITERATURE STUDY Buying decision}

(Kotler \& Armstrong, 2017)revealed that the buying decision is the stage in the buyer's decision-making process where consumers actually buy.(Schiffman \& Kanuk, 2010)argued that the buying decision is the behavior shown by consumers in seeking, giving, using, evaluating, and spending a product and service that is expected to satisfy their needs.

buying decisions can be measured using indicators as disclosed by(Sholihat \& Rumyeni, 2018)namely stability on a product, habits in buying products, providing recommendations to others, and making repeat purchases. This indicator was chosen because it is in accordance with the research model built in this study.

\section{Purchase Intention}

(Mubarok, 2018)argued that purchase intention is obtained through a learning process and a thought process that forms a perception. Purchase intention can be used to test the implementation of new distribution channels to help managers determine whether the concept is feasible for further development and decide which geographic markets and consumer segments to target through the channel(Peña-García, Gil-Saura, Rodríguez-Orejuela, \& Siqueira-Junior, 2020).

(Kala \& Chaubey, 2018)argued that purchase intention can be said to be one of the main components of consumer cognitive behavior that shows a blueprint for consumer awareness to tend to buy a brand. If buyers perceive a product as high quality, they will value it more highly and will show a higher willingness to buy it(Weisstein, Asgari, \& Siew, 2014).The intention is an indication of one's readiness to show behavior which is an antecedent of behavior.

In this study, the measurement of purchase intention uses indicators as disclosed by(Pentury, Sugianto, \& Remiasa, 2019)namely transactional interests, referential interests, preferential interests, and explorative interests. This indicator was chosen because it fits the model built in this study.

\section{Brand Image}

(Rangkuti, 2017)stated brand image is a perception about a brand that is associated with brand associations that are inherent in consumer memories. Meanwhile obeyed(Sopiah \& Sangadji, 2018)A brand image is a unique set of associations that marketers want to create or maintain, wherein the Association defines what a brand really is and what it promises to consumers. (Kotler \& Keller, 2018)mentioned the brand image has six levels, namely attributes, benefits, values, culture, personality, and users. Brand image can be measured using indicators as expressed by(Rahmi \& Nizam, 2017)namely recognition, reputation, affinity, and domain. This indicator was chosen because it fits the model built in this study. 


\section{International Journal of Business Management and Economic Review}

Vol. 4, No. 02; 2021

ISSN: 2581-4664

\section{Lifestyle}

(Kotler \& Keller, 2018)explained that lifestyle is a lifestyle of a person in the world that is reflected in AIO, namely Activities, Interests, and Opinions. Also according to(Schiffman \& Kanuk, 2010),In marketing, a lifestyle is called a psychographic which includes activities, interests, and consumer opinions.

Meanwhile (Solomon, 2019)expressed Lifestyle reflects consumption patterns that describe a person's choice of how he uses his time and money. For someone who comes from the same sub-culture, social class, and occupation, it is very possible to have a different lifestyle. Lifestyle can be measured using indicators as expressed by(Kotler \& Armstrong, 2017)namely activities, interests, and opinions.

\section{Price}

(Kotler \& Keller, 2018)expressed price is the amount of money (possibly several items weighed) required to obtain some combination of a product and the accompanying service. Meanwhile(Kotler \& Armstrong, 2017)stated the price as the amount of value charged for a product or service or the amount of value that consumers exchange for benefits due to owning or using the product or service.

(Tjiptono, 2017)stated price is something that is given up in exchange for a good or service. consumer price perceptions are strongly influenced by brand image. Prices can be measured using the indicators disclosed by(Anggraini, Hidayat, \& Sunarti, 2019), namely affordability, suitability, competitiveness.

\section{conceptual framework}

This research conceptual framework will explain the relationship between each variable on increased loyalty, which can be described as follows :

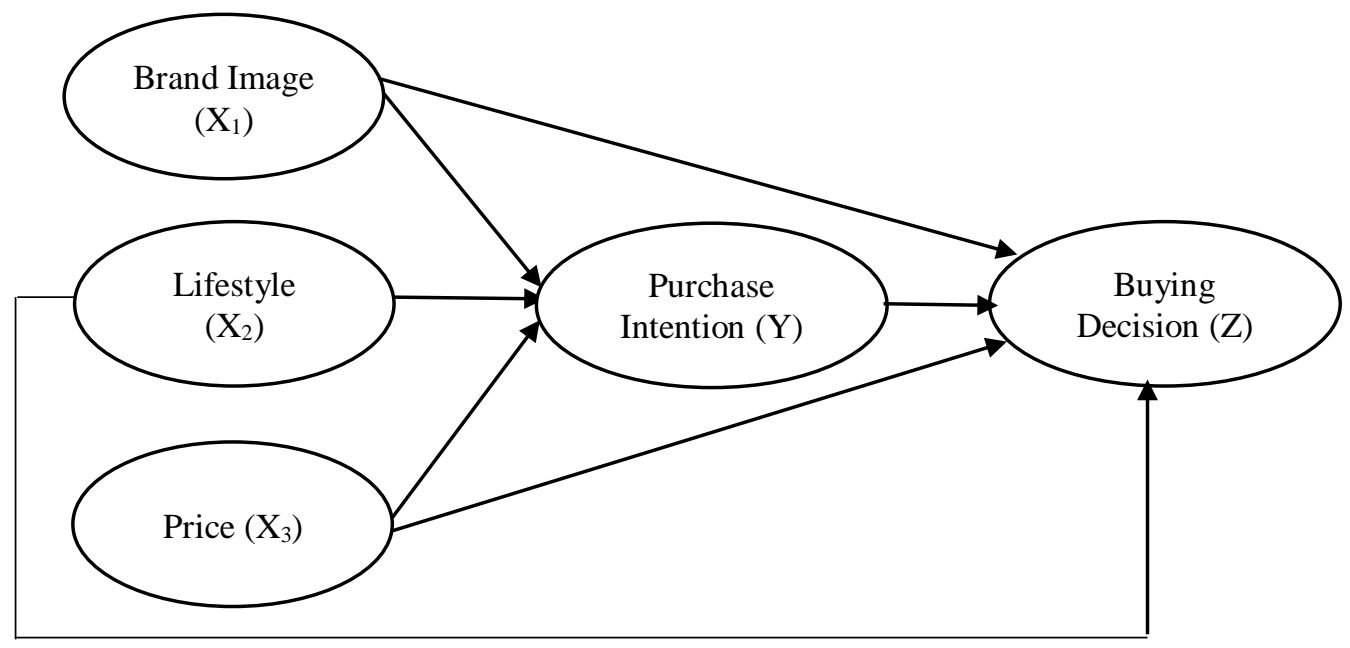

Figure 1. Conceptual Framework

H1 : Brand image significantly influences the purchase intention of Gojek online transportation 
Vol. 4, No. 02; 2021

ISSN: 2581-4664

service users in Banda Aceh City.

$\mathrm{H} 2$ : Lifestyle significantly influences the purchase intention of Gojek online transportation service users in Banda Aceh City.

H3 : Price significantly influences the purchase intention of Gojek online transportation service users in Banda Aceh City.

H4 : Brand image significantly influences buying decisions of Gojek online transportation service users in Banda Aceh City.

H5 : Lifestyle significantly influences the buying decisions of Gojek online transportation service users in Banda Aceh City.

H6 : Price significantly influences the buying decisions of Gojek online transportation service users in Banda Aceh City.

H7 : Purchase intention significantly influences the buying decision of Gojek online transportation service users in Banda Aceh City

H8 : Purchase intention mediates the influence of brand image on buying decisions of Gojek online transportation service users in Banda Aceh City.

H9 : Purchase intention mediates the influence of lifestyle on buying decisions of Gojek online transportation service users in Banda Aceh City.

H10: Purchase intention mediates the effect of price on buying decisions of Gojek online transportation service users in Banda Aceh City

\section{METHOD}

This research was conducted in the city of Banda Aceh, Indonesia. The research objectwas the users of online transportation services. The sample taken was consumers of Gojekonline transportation service users in the city of Banda Aceh using a non-probability sampling method with a quota sampling technique in order to obtain a sample of 197 people.

Data were collected by using questionnaires and analyzed using Structural Equation Modeling (SEM) using Amos software. The questionnaires in this study consisted of two parts, namely the first part covered the characteristics of the respondent, while the second part attached questions made following the research variables. Five research variables were consisting of buying decisions $(\mathrm{Z})$, purchase intention $(\mathrm{Y})$, brand image (X1), lifestyle (X2), and price (X3). Each question for the questionnaire will represent each indicator of the variable to be studied.

\section{RESULTS AND DISCUSSION \\ Results}

Direct Hypothesis

The structural model analysis explaining the effect test between variables is presented in the following path diagram: 


\section{International Journal of Business Management and Economic Review}

Vol. 4, No. 02; 2021

ISSN: 2581-4664

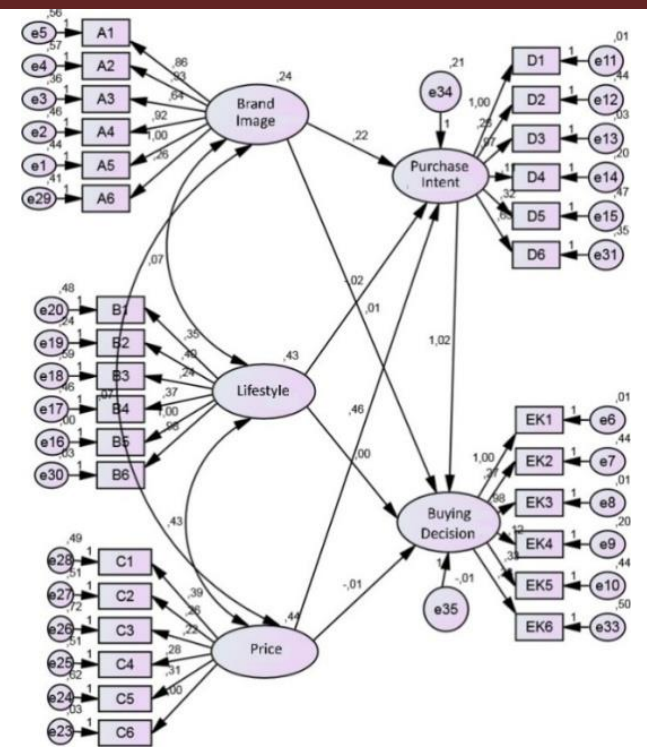

Figure 2. Test Results

The full model test results for testing the direct effect hypothesis after fulfilling the SEM assumptions are more clearly shown in the following table:

Table 1. Hypothesis Test Results

\begin{tabular}{|c|c|c|c|c|c|c|}
\hline & & & $\begin{array}{l}\text { Estimat } \\
\mathrm{e}\end{array}$ & S.E. & C.R. & $\mathrm{P}$ \\
\hline Purchase Intent & <-- & Brand Image & 0.216 & $\begin{array}{l}0.09 \\
5\end{array}$ & $\begin{array}{l}2.27 \\
5\end{array}$ & $\begin{array}{r}0.02 \\
3\end{array}$ \\
\hline Purchase Intent & <-- & Lifestyle & 0.017 & $\begin{array}{l}0.98 \\
9\end{array}$ & $\begin{array}{l}2.01 \\
7\end{array}$ & $\begin{array}{r}0.01 \\
6\end{array}$ \\
\hline Purchase Intent & <-- & Price & 0.458 & $\begin{array}{l}0.98 \\
2\end{array}$ & $\begin{array}{l}2.46 \\
7\end{array}$ & 0.041 \\
\hline Buying Decision & <-- & Brand Image & 0.010 & $\begin{array}{l}0.01 \\
1\end{array}$ & $\begin{array}{l}2.88 \\
7\end{array}$ & $\begin{array}{r}0.03 \\
5\end{array}$ \\
\hline Buying Decision & $<-$ & Lifestyle & -0.001 & $\begin{array}{l}0.08 \\
3\end{array}$ & $\begin{array}{l}- \\
2.018\end{array}$ & $\begin{array}{r}0.02 \\
6 \\
\end{array}$ \\
\hline Buying Decision & <-- & Price & -0.010 & $\begin{array}{l}0.08 \\
3 \\
\end{array}$ & $\begin{array}{l} \\
\end{array} .118$ & 0.006 \\
\hline Buying Decision & - & Purchase Intent & 1.023 & $\begin{array}{l}0.01 \\
2\end{array}$ & $\begin{array}{l}2.13 \\
3\end{array}$ & $\begin{array}{r}0.00 \\
0\end{array}$ \\
\hline
\end{tabular}

Source: Primary data, 2021 (processed)

Based on the results of SEM analysis in Table 1 and statistical equations (1) and (2), the following results can be formulated:

Purchase Intention $=0.216$ Brand Image +0.017 Lifestyle +0.458 buying Decision Price $=$ 


\section{International Journal of Business Management and Economic Review}

Vol. 4, No. 02; 2021

ISSN: 2581-4664

0.010 Brand Image - 0.001 Lifestyle - 0.010 Price + 1.023 Purchase Intention.

The results of the direct effect test are as follows:

1. H1: The effect of brand image on purchase intentions obtained a CR value of 2.275 with a significance level of 0.023 . These two values explain that a brand image can significantly influence purchase intentions. The magnitude of the influence of brand image on purchase intention is 0.216 or $21.6 \%$. This reveals that the better the brand image, it will have a significant influence in a positive direction in increasing purchase intention. The results of this study are relevant to(Kala \& Chaubey, 2018)(Rahmi \& Nizam, 2017); (Hsieh, 2016). They revealed that brand image plays a role in increasing purchase intention. This is because the brand image is an important priority that consumers will consider. In addition, the brand image will be a reference before consumers raise their intention to make a purchase. Thus, brand image has an effect on increasing purchase intention

2. H2: The effect of lifestyle on purchase intentions obtained a CR value of 2.017 with a significance level of 0.016 . These two values explain that a lifestyle can significantly influence purchase intentions. The magnitude of the influence of lifestyle on the increase in purchase intention is 0.017 or $1.7 \%$. This reveals that the better the lifestyle, it will affect increasing purchase intentions. The results of this study are relevant to(Saputra, Lubis, \& Nizam, 2020),(Indrayani \& Nurcaya, 2014)dan(Qing, Lobo, \& Chongguang, 2012). They revealed that lifestyle has an effect on increasing purchase intention. This is because the lifestyle encourages consumers to make their intention to shop. In other words, it can be said that lifestyle has an effect on increasing purchase intention

3. H3: The effect of price on purchase intentions obtained a CR value of 2.467 with a significance level of 0.041 . These two values explain that the price can significantly influence purchase intentions. The magnitude of the effect of price on the increase in purchase intentions is 0.458 or $45.8 \%$. This indicates that the higher the price, the effect of increasing purchase intention will be. The results of this study are relevant to Satriawan and Putu, (2020); Lien, (2015). They revealed that price has a positive effect on purchase intention. This is because they think that the price will reflect a quality product or service. It cannot be denied that price will be a consideration to increase purchase intention

4. H4: The effect of brand image on buying decisions obtained a CR value of 2.887 with a significance level of 0.035 . These two values explain that the brand image can significantly influence buying decisions. The magnitude of the influence of brand image on buying decisions is 0.010 or $1.0 \%$. This indicates that the better the brand image will have a positive and real effect on increasing buying decisions. The results of this study are relevant to (Sari, 2019); (Mubarok, 2018); (Wardana, 2016); and (Oladepo, 2015). They revealed that brand image plays a role in increasing purchase intention. This is because the brand image is an important priority that consumers will consider. In addition, the brand image will be a reference before consumers raise their intention to make a purchase. Thus, brand image has an effect on increasing purchase intention

5. H5: The effect of lifestyle on buying decisions obtained a CR value of -2.018 with a significance level of 0.026 . These two values explain that lifestyle can significantly influence buying decisions. The magnitude of the influence of lifestyle on decreasing buying decisions is -0.001 or $0.1 \%$. This indicates that the better the lifestyle, the lower the buying decision 
Vol. 4, No. 02; 2021

ISSN: 2581-4664

will be. The results of this study are not relevant to WijayaDarma (2017); Kapantouw, (2015); Lemiyana, (2019). They revealed that lifestyle has an effect on increasing buying decisions. This is because the lifestyle encourages consumers to make their intention to shop. However, in this study, it was found that lifestyle has an effect on reducing buying decisions

6. H6: The effect of price on buying decisions obtained a CR value of CR2,118 with a significance level of 0.006 . These two values explain that the price can significantly influence buying decisions. The magnitude of the effect of price on decreasing buying decisions is -0.010 or $1.0 \%$. This indicates that the higher the price, the lower the buying decision will be. The results of this study are not relevant to Wardana, (2016); and Satriawan and Putu, (2020). They revealed that price has a positive effect on buying decisions. However, in this study, it was found that prices actually lowered buying decisions.

7. H7: The effect of purchase intention on buying decisions obtained a CR value of 2.133 with a significant level of 0.000 . These two values explain that purchase intention can significantly influence buying decisions. The magnitude of the influence of purchase intentions on the increase in buying decisions is 1.023 or $102.3 \%$. This indicates that the higher the purchase intention, it will affect increasing buying decisions. The results of this study are relevant to Mubarok, (2018); and Lim et al., (2016). They found that purchase intention affects increasing buying decisions. This is because when the intention has appeared in the consumer's view, it will be realized in the form of a buying decision. In other words, purchase intention can improve buying decisions

Indirect Hypothesis (Mediation)

The results of testing the indirect hypothesis (mediation) are described below:

1. H8: Testing the Influence of Brand Image on buying Decisions through Purchase Intention as can be seen in the following figure:

2.

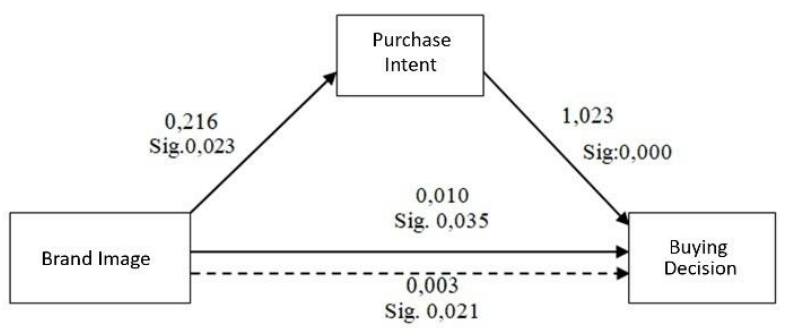

Figure 3.The Results of Hypothesis Mediation 8

In Figure 3 above, it can be seen that the direct path coefficient between brand image and buying decisions has a value of 0.010 . Meanwhile, the indirect path coefficient between brand image and buying decision has a value of 0.003 . These two figures reveal that brand image has a greater direct influence on buying decisions, rather than through purchase intentions. Thus, because the direct influence is greater than the effect of mediation, it can be concluded that the mediating variable in the research model acts as partial mediator. 
Vol. 4, No. 02; 2021

ISSN: 2581-4664

3. H9: testing the Effect of Lifestyle on buying Decisions through Purchase Intention as shown in the following figure.

4.

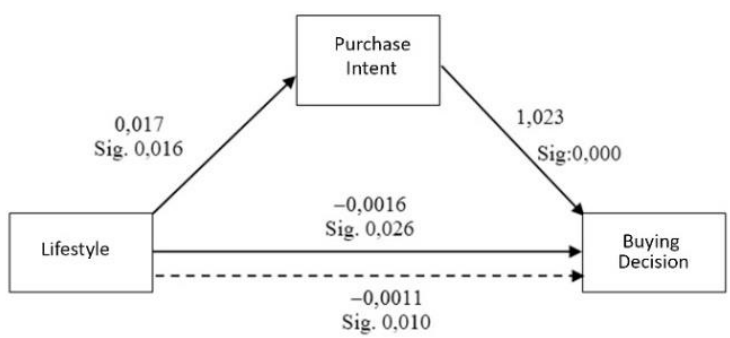

Figure 4. The Results of Hypothesis Mediation 9

Based on Figure 4 above, it can be seen that the direct path coefficient between lifestyle and buying decisions has a value of -0.0016 . While the indirect path coefficient between lifestyle and buying decisions has a value of -0.0011 . Both of these figures explain that lifestyle has a greater direct influence on buying decisions, rather than through purchase intentions. Thus, because the direct effect is greater than the effect of mediation, it can be concluded that the mediating variable in the research model acts as partial mediator.

5. H10: Testing the Effect of Price on Buying Decisions through Purchase Intention as shown in the following figure:

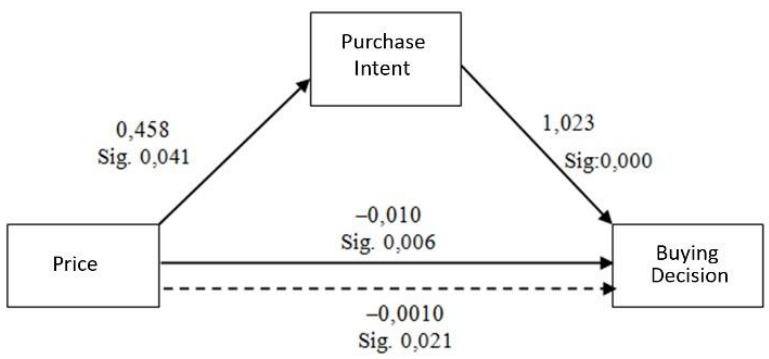

Figure 5.The Results of Hypothesis Mediation 10

From Figure 5 above, it can be seen that the direct path coefficient between price and buying decision has a value of -0.010 . While the indirect path coefficient between price and buying decision has -0.0010 . This shows that the price has a greater direct influence on buying decisions, rather than having to go through the purchase intention. Thus, because the direct influence is greater than the effect of mediation, it can be concluded that the mediating variable in the research model acts as a partial mediator.

\section{Discussion}

Some data show that the problems for the variables can be given attention by online transportation service manufacturers for the target city of Banda Aceh. Social status as an indicator of brand image gets the lowest score than other indicators. This indicates that social status is not the main reason every passenger wants to use motorbike taxi services. Social status 


\section{International Journal of Business Management and Economic Review}

Vol. 4, No. 02; 2021

ISSN: 2581-4664

symbols today are no longer the main factor in using a brand with an image in it. Only certain segments rely on social status as the main factor in choosing a brand with an image attached to it.

The lifestyle variable has one of the indicators with the lowest value, namely spending money on important things. The low level of respondents' statements regarding this indicator proves that the motorbike taxi can develop with its platforms and services, but because there are still many people who have a low economic level and some are still able to use their own vehicles, the motorbike taxi does not fully play an important role in daily activities. The price offered by motorbikes in using their services is felt to be a little high compared to the ability of most of the community, so education is needed about mental safety and improving the quality of service at motorbikes. This was taken to accommodate all segments in its business regarding tariffs and to ensure that Gojek would continue to dominate market share.

Preferential interest has not proved to be one of the priority factors because consumers are still in the vicinity of current services, without thinking about ensuring that they continue to use motorbike taxi services in routine transportation in the future. This statement is in accordance with the lowest value obtained regarding consumer preferential interest as an indicator of the purchase intention variable. The majority of respondents' responses regarding the re-purchase of services provided by motorbikes indicate that not all consumers have experienced satisfaction using the services provided. There are still things that consumers feel about motorbike taxi services that are not yet suitable and in accordance with the ability/purchasing power of the community.

\section{CONCLUSION}

The research found that brand image, lifestyle, and price directly influence purchase intentions; brand image, lifestyle, price, and purchase intention influence buying decisions, and; purchase intention partially mediates the influence of lifestyle and the effect of price on buying decisions. These findings prove that the current research model can represent previous theories of causality. The novelty lies in the finding of purchase intention which acts as a partial mediator in the use of online transportation services in Banda Aceh. These findings contribute to the academic world, which can be the basis for further research which can be devoted to online transportation, and the addition of other variables such as gender, distance, or others as moderating variables, which can be indicative of decisions on using online transportation. For practitioners, especially manufacturers of online transportation services, this research model can be the basis for re-establishing service strategies for the work area of the city of Banda Aceh. Producers need to pay attention to social status, expenditure for important things, tariffs, and preferential interests of producers in the future, in order to find the right strategy formulation to increase the use of society in online transportation services.

\section{REFERENCES}

Anggraini, E. I., Hidayat, K., \& Sunarti. (2019). Pengaruh Kualitas Produk Dan Harga Terhadap Keputusan Pembelian (Survei pada Pembeli yang juga Menggunakan Kosmetik Wardah di Counter Wardah Matahari Department Store Malang Town Square ). Jurnal Administrasi Bisnis, $7(1), 118-124$.

Hsieh, H.-Y. (2016). The Relationship among Consumer Value, Brand Image, Perceived Value and Purchase Intention- A Case of Tea Chain Store in Tainan City. Proceedings of the Eighth 


\section{International Journal of Business Management and Economic Review}

Vol. 4, No. 02; 2021

ISSN: 2581-4664

Asia-Pacific Conference on Global Business, Economics, Finance and Banking (AP16 Singapore Conference), 21-23. Singapure: globalbizresearch.

Indrayani, L., \& Nurcaya, I. N. (2014). Peran Persepsi Kualitas Produk Dalam Memediasi Pengaruh Gaya Hidup Terhadap Niat Beli Handphone Samsung Galaxy Di Kota Denpasar. EJurnal Manajemen, 3(4), 885-901.

Kala, D., \& Chaubey, D. S. (2018). The effect of eWOM communication on brand image and purchase intention towards lifestyle products in India. International Journal of Services Economics and Management, 9(2), 143-157. https://doi.org/10.1504/IJSEM.2018.10017351

Kotler, P., \& Armstrong, G. (2017). Principles of Marketing (17th ed.). London: Pearson.

Kotler, P., \& Keller, K. L. (2018). Marketing Management, Global Edition (15th editi). Harlow, United Kingdom: Pearson.

Mubarok, M. M. (2018). Pengaruh Brand Image Dan Sikap Konsumen Terhadap Keputusan Pembelian Batik Jetis Sidoarjo Dimediasi Oleh Minat Beli. INA-Rxiv, Center for Open Science, sdrf5, 1-20. https://doi.org/10.31227/osf.io/sdrf5

Peña-García, N., Gil-Saura, I., Rodríguez-Orejuela, A., \& Siqueira-Junior, J. R. (2020). Purchase intention and purchase behavior online: A cross-cultural approach. Heliyon, 6(6), 1-11. https://doi.org/https://doi.org/10.1016/j.heliyon.2020.e04284

Pentury, L. V., Sugianto, M., \& Remiasa, M. (2019). Pengaruh E-Wom Terhadap Brand Image Dan Purchase Intention Pada Hotel Bintang Tiga Di Bali. Jurnal Manajemen Perhotelan, 5(1), 26-35. https://doi.org/https://doi.org/10.9744/jmp.5.1.26-35

Qing, P., Lobo, A., \& Chongguang, L. (2012). The impact of lifestyle and ethnocentrism on consumers' purchase intentions of fresh fruit in China. Journal of Consumer Marketing, 29(1), 43-51. https://doi.org/10.1108/07363761211193037

Rahmi, D. T., \& Nizam, A. (2017). Pengaruh Citra Merek Terhadap Niat Pembelian Tiket Pesawat Secara Online Pada Konsumen Traveloka.Com Dengan Kepercayaan Sebagai Variabel Mediasi. Jurnal Ilmiah Mahasiswa Ekonomi Manajemen, 2(3), 70-85. https://doi.org/https://doi.org/10.24815/jimen.v2i3.3522

Rangkuti, F. (2017). Customer Care Excellence. Jakarta: Gramedia Pustaka Utama.

Saputra, A. M., Lubis, P. H., \& Nizam, A. (2020). Factors Impacting Millennial Online Purchase Intention With Web Experience Intensity As Moderation. International Journal of Business Management and Economic Review, 3(3), 1-16. https://doi.org/http://doi.org/10.35409/IJBMER.2020.3174

Schiffman, L., \& Kanuk, L. (2010). Consumer Behavior (11th ed.). London: Pearson.

Sholihat, A., \& Rumyeni. (2018). Pengaruh Promosi Penjualan Dan Kualitas Pelayanan Terhadap Keputusan Pembelian Di Krema Koffie. Jurnal Online Mahasiswa (JOM) Bidang Ilmu Sosial Dan Ilmu Politik, 5(1), 1-15.

Solomon, M. R. (2019). Consumer Behavior: Buying, Having, Being (13th ed.). London: Pearson. 
International Journal of Business Management and Economic Review

Vol. 4, No. 02; 2021

ISSN: 2581-4664

Sopiah, \& Sangadji, E. M. (2018). Manajemen Sumber Daya Manusia Strategik. Yogyakarta: Andi Publisher.

Tjiptono, F. (2017). Strategi pemasaran (4th ed.). Jakarta: Andi.

Weisstein, F. L., Asgari, M., \& Siew, S.-W. (2014). Price presentation effects on green purchase intentions. Journal of Product \& Brand Management, 23(3), 230-239. https://doi.org/10.1108/JPBM-06-2013-0324 